\title{
PENDIDIKAN AGAMA ISLAM PADA SEKOLAH BERBASIS PESANTREN: STUDI KASUS PADA SMP AL MUTTAQIN KOTA TASIKMALAYA
}

\section{ISLAMIC RELIGIOUS EDUCATION IN PESANTREN-BASED SCHOOL: CASE STUDY IN SMPBP AL MUTTAQIN TASIKMALAYA CITY}

\author{
Juju Saepudin \\ Balai Penelitian dan Pengembangan Agama Jakarta \\ Jl. Rawa Kuning No.6 Pulo Gebang Cakung, Jakarta Timur \\ email: saep.17.khasep@gmail.com
}

Naskah Diterima: 22 Januari 2019; Direvisi: 08 Maret 2019; Disetujui: 23 Agustus 2019

\begin{abstract}
Pesantren-Based Schools (SBP) are integrated education models that combine the implementation of a schooling system that develops science and skills abilities with the implementation of a pesantren system that develops religious attitudes and practices, increased morality and independence in life. This paper presents the results of a study of the model of Islamic Education (PAI) in Pesantren-based Junior High School (SMPBP) Al Muttaqin in Tasikmalaya City. Data was collected by interview, observation and document study techniques. The results of the study and discussion found several conclusions as follows: First, the structure of the PAI curriculum is not limited in the number of limited hours, but was reduced to a sub-field of study which is part of the PAI family, even modified in local content that is typical of pesantren. Second, PAI is not limited to a subject, but it becomes a system so that it is not limited to formal space and time. Third, the implications of the development of PAI can improve student achievement and prestige in the eyes of parents and the community, as well as making SMPBP Al Muttaqin as a magnet in the acceptance of new students as evidenced by increasing interest.
\end{abstract}

Keywords: Islamic Education; Pesantren Based Schools; SMPBP Al Muttaqin Tasikmalaya City

\begin{abstract}
Abstrak
Sekolah Berbasis Pesantren (SBP) merupakan model pendidikan integrasi yang menggabungkan pelaksanaan sistem persekolahan yang mengembangkan kemampuan sains dan keterampilan dengan pelaksanaan sistem pesantren yang mengembangkan sikap dan praktik keagamaan, peningkatan moralitas dan kemandirian dalam hidup. Tulisan ini menyajikan hasil penelitian tentang Pendidikan Agama Islam (PAI) Pada Sekolah Menengah Pertama Berbasis Pesantren (SMPBP) Al Muttaqin Kota Tasikmalaya. Data dikumpulkan dengan teknik wawancara, observasi, dan studi dokumen. Berdasarkan hasil analisis dan pembahasan ditemukan beberapa kesimpulan sebagai berikut: Pertama, secara struktur kurikulum PAI tidak dibatasi dalam jumlah jam pelajaran yang terbatas, namun diturunkan menjadi sub bidang studi yang merupakan bagian dari rumpun PAI, bahkan dimodifikasi dalam muatan lokal yang bernuansa khas pesantren. Kedua, PAI tidak terbatas sebagai sebuah mata pelajaran, tatapi menjadi sebuah sistem sehingga tidak dibatasi ruang dan waktu yang formal. Ketiga, implikasi dari pengembangan PAI dapat meningkatkan prestasi dan prestise siswa di mata orang tua dan masyarakat, juga menjadikan SMPBP Al Muttaqin sebagai magnet dalam penerimaan peserta didik baru yang dibuktikan dengan peminat yang terus meningkat.
\end{abstract}

Kata Kunci: Pendidikan Agama Islam; Sekolah Berbasis Pesantren; SMPBP Al Muttaqin Kota Tasikmalaya 


\section{PENDAHULUAN}

Sekolah dan pondok pesantren merupakan dua institusi pendidikan yang masing-masing memiliki keunggulan yang berbeda satu sama lain. Apabila keunggulan dari kedua lembaga pendidikan itu dipadukan, maka akan tercipta sebuah kekuatan pendidikan yang kuat dan berpotensi mampu menghasilkan generasi muda Indonesia yang unggul, handal dan berkarakter (Suhardi, 2012). Namun sayangnya muncul dikotomi antara pendidikan sekolah dan pondok pesantren, sehingga pesantren dan sekolah dipandang secara fenomenologi sebagai bentuk idealisme pada masing-masing lembaga pendidikan tersebut (Craib, 1992).

Persoalan itu terjadi hampir merata di setiap dunia pendidikan yang ada di Indonesia. Lembaga-lembaga pendidikan yang memiliki konsentrasi dan orientasi yang berbeda seolaholah tidak bisa bersatu dalam sebuah sistem pendidikan atau harus berpisah. Ada lembaga yang menitikberatkan orientasinya pada ilmuilmu modern dan di sisi lain ada juga lembaga yang hanya memfokuskan diri pada ilmu-ilmu tradisional, realitas seperti ini dikenal dengan dualisme Pendidikan (Sutrisno and Muhyidin, 2012). Untuk mengakomodasi dikotomi tersebut, Sekolah Berbasis Pesantren (SBP) berupaya mengintegrasikan keunggulan sistem pendidikan sekolah dengan penyelenggaraan pendidikan di pondok pesantren. Langkah ini dimaksudkan agar kultur positif yang berkembang di pesantren dapat diadopsi oleh sekolah dan diintegrasikan ke dalam berbagai aspek proses pendidikan di sekolah dan sebaliknya keunggulan di sekolah bisa diterapkan dipesantren.

Sekolah Berbasis Pesantren merupakan salah satu model pendidikan Islam yang menggabungkan dua sistem sosial, yaitu pondok pesantren dan institusi sekolah. Pondok pesantren dan pendidikan sekolah memiliki sistem sosial dan keunggulan masing-masing. SBP bertujuan untuk menciptakan sumber daya manusia memiliki iman dan takwa sekaligus menguasai ilmu pengetahuan dan teknologi secara utuh, sehingga dapat berperan dalam sistem sosial kemasyarakatan. SBP merupakan salah satu fakta sosial, yang muncul karena adanya kesadaran dan hasil pemikiran dari berbagai pihak, serta diskusi antar lembaga, seperti: Kementerian Agama, Kementerian Pendidikan Nasional, Centre for Educational Development (CERDEV) UIN Syarif Hidayatullah Jakarta, Pesantren, dan Sekolah.

Upaya memadukan pendidikan sekolah formal dengan pondok pesantren akan menghasilkan sistem pendidikan yang lebih kuat dan lengkap. Keunggulan yang terdapat pada masing-masing lembaga pendidikan itu akan semakin bermakna apabila keduanya diintegrasikan ke dalam satu model satuan pendidikan yang dikelola secara terpadu. Integrasi ini akan menjadi instrumen yang berharga bagi peningkatan mutu Sumber Daya Manusia (SDM) di Indonesia sehingga menjadi manusia yang kompetitif dan komparatif serta mampu bersaing di era globalisasi tanpa harus meninggalkan karakter bangsa.

Pada tahun 2008, Kementerian Pendidikan dan Kebudayaan (Kemendikbud) dan Kementerian Agama (Kemenag) menjalin kerja sama untuk melaksanakan Program Pengembangan SBP. Kerja sama ini dituangkan dalam kesepakatan bersama antara Direktur Pembinaan Sekolah Menengah Pertama dan Direktur Pendidikan Diniyah dan Pondok Pesantren Nomor 815/C3/LL/2008 dan Nomor Dt.I.III/83/2008 tentang Pengembangan Sekolah Menengah Pertama Berbasis Pesantren. Pada 2013 program itu dilanjutkan berdasarkan Kesepakatan Bersama antara Direktur Pembinaan Sekolah Menengah Pertama dan Direktur Pendidikan Diniyah dan Pondok Pesantren Nomor 1763.1/C3/KP/2013 dan Nomor Dj.I/Dt.i.III/3/PP.00.7/2509/2913 tentang Pengembangan Sekolah Menengah Pertama Berbasis Pesantren.

Menurut Rosada (2009), pada tahap awal program ini dilaksanakan untuk tingkat Sekolah Menengah Pertama (SMP), karena pada tahap ini usia anak sedang mengalami masa pengembangan karakter yang paling penting dalam fase kehidupan manusia. Fase ini dikenal dengan sebutan Period of Formal Operation. Pada usia ini, seseorang sedang mengalami fase pencarian jati diri yang ditandai dengan kemampuan berpikir secara simbolis dan bisa memahami sesuatu secara bermakna (meaningfully) tanpa memerlukan 
objek yang kongkret, bahkan objek visual sekalipun.

Jumlah SMP Berbasis Pesantren (SMPBP) terus mengalami peningkatan setiap tahun. Berdasarkan data dari Kementerian Pendidikan dan Kebudayaan (2016), pada awal dideklarasikan tahun 2008 berjumlah 25 anggota dan pada akhir tahun 2015 tercatat berkembang menjadi 302 SMPBP yang tersebar di berbagai provinsi. Secara akademik, prestasi peserta didik SMPBP mengalami kenaikan nilai Ujian Nasional (UN) sesuai standar dengan angka kelulusan $100 \%$. Semua peserta didik lulusan SMPBP $100 \%$ dapat melanjutkan ke jenjang pendidikan yang lebih tinggi sesuai dengan keinginannya. Begitu juga dengan perolehan akreditasi terjadi peningkatan hingga saat ini SMPBP yang memperoleh akreditasi A sebanyak 30\%, terakreditasi B sebanyak $60 \%$, terakreditasi C sebanyak 10\% (Nurochim, 2016).

Berbagai prestasi dan keunggulan tersebut di atas, merupakan satu bukti nyata keberhasilan dari program SBP. Poin penting lainnya yang perlu dikaji selanjutnya adalah bagaimana kemajuan yang dicapai SBP dalam hal penguasaan pengetahuan agama dan praktik kultur kepesantrenan? Tulisan ini berusaha melengkapi kajian-kajian yang sudah dilakukan di atas dengan mengambil tema tentang "Pendidikan Agama Islam Pada SMP Berbasis Pesantren Al-Mutaqin Kota Tasikmalaya."

Fokus utama dalam penelitian ini adalah: (1) pengembangan PAI yang dilakukan SMPBP Al-Mutaqin Kota Tasikmalaya; (2) implementasi PAI di SMPBP Al-Mutaqin Kota Tasikmalaya; dan (3) implikasi serta faktor pendukung dan kendala dalam menjalankan program pengembangan PAI di SMPBP AlMutaqin Kota Tasikmalaya.

Penelitian ini diharapkan bisa memberi masukan kepada pemangku kebijakan dalam rangka pengembangan model pendidikan yang efektif dan inovatif, juga memberi manfaat bagi seluruh stakeholders pendidikan baik masyarakat umum maupun lembaga penyelenggara pendidikan. Melalui penelitian ini publik menemukan kasus yang dapat diteladani sebagai lesson learn tentang penyelenggaraan pendidikan dengan memenuhi layanan agama sesuai agama anak. Model PAI pada SBP dapat membangun optimisme pemerintah dan pengamat serta pemerhati pendidikan agama tentang upaya memosisikan sekolah sebagai ujung tombak membangun budaya toleransi dan multikulturalisme dalam kehidupan berbangsa dan bernegara.

\section{KERANGKA KONSEPTUAL}

\section{Pendidikan Agama Islam}

Pendidikan lebih dari pada sekedar pengajaran. Pengajaran dapat dikatakan sebagai suatu proses transfer ilmu belaka, namun pendidikan merupakan transformasi nilai dan pembentukan kepribadian dengan segala aspek yang dicakupnya. Dengan demikian, pengajaran lebih berorientasi pada pembentukan "tukang-tukang" atau para spesialis yang lebih bersifat teknis. Perbedaan pendidikan dengan pengajaran terletak pada penekanan pendidikan terhadap pembentukan kesadaran dan kepribadian anak didik di samping transfer ilmu dan keahlian (Azra, 1999).

Mengambil makna dari pandangan tersebut, pendidikan secara umum memuat sebuah usaha dan cara-cara yang dipersiapkan oleh pelaku pendidikan dengan persiapan yang matang dan penekanan-penekanan menuju ke arah proses transformasi nilai dan pembentukan kepribadian yang sesungguhnya tidak mudah dilaksanakan. Jika kemudian dihubungkan dengan Islam sebagai sistem keagamaan kata pendidikan menimbulkan pengertian-pengertian baru dengan penekanan dan karakteristik yang berbeda-beda sesuai dengan cara pandang yang digunakan oleh para ahli.

Peraturan Pemerintah Nomor 55 Tahun 2007, pasal 1 menyatakan bahwa pendidikan agama adalah pendidikan yang memberikan pengetahuan dan membentuk sikap, kepribadian, dan keterampilan peserta didik dalam mengamalkan ajaran agamanya, yang dilaksanakan sekurang-kurangnya melalui mata pelajaran/kuliah pada semua jalur, jenjang, dan jenis pendidikan. Sedangkan menurut Daradjat (1992), pendidikan agama adalah suatu usaha yang secara sadar dilakukan 
guru untuk mempengaruhi siswa dalam rangka pembentukan manusia beragama.

Pendidikan agama dimaksudkan untuk membentuk peserta didik menjadi manusia yang beriman dan bertakwa kepada Tuhan Yang Maha Esa serta berakhlak mulia. Oleh sebab itu, dibutuhkan berbagai usaha dan ikhtiar yang sistematis dan sinergis dari berbagai pihak. Masing-masing pihak dapat menjalankan tugas dan fungsinya sesuai dengan kemampuan dan ruang lingkup kewenangan yang dimiliki. Setiap orang tua dapat mengajarkan dan mendidik anakanaknya di rumah, masyarakat bisa menyediakan berbagai sarana dan prasarana pengamalan ibadah sebagai bentuk pendidikan praktis kepada anak didik. Pemerintah daerah dan pemerintah pusat dituntut untuk membuat berbagai regulasi dan kebijakan yang kondusif bagi peserta didik dan masyarakat untuk mendalami dan mempelajari serta mengamalkan ajaran agama yang dianutnya (Hayadin, 2017).

Pendidikan Islam dipandang sebagai sebuah usaha dan cara kerja yang memiliki tiga karakter, yaitu: Pertama, pendidikan Islam memiliki karakter penekanan pada pencarian dan penguasaan ilmu pengetahuan. Kedua, pendidikan Islam merupakan sebuah pengakuan akan potensi dan kemampuan seseorang untuk berkembang dalam suatu kepribadian. Ketiga, pendidikan Islam merupakan sebuah pengalaman ilmu atas dasar tanggung jawab kepada Tuhan yang Maha Esa (Azra, 1999). Dari sini jelas bahwasanya pendidikan Islam sebagai sebuah usaha manusia biasa yang menempati posisi mulia sebagai tugas kemanusiaan dan kehambaan, karena terjalin dalam rangka hubungan antara manusia sekaligus bernilai ibadah kepada tuhan.

Pendidikan Agama Islam (PAI) adalah bagian integral daripada pendidikan nasional sebagai suatu keseluruhan. Dalam UU No. 20/2003 tentang Sistem Pendidikan Nasional pasal 37 ayat 1 dijelaskan bahwa kurikulum pendidikan dasar dan menengah wajib memuat antara lain pendidikan agama. Dalam penjelasannya dinyatakan bahwa pendidikan agama dimaksudkan untuk membentuk peserta didik menjadi manusia yang beriman dan bertakwa kepada Tuhan Yang Maha Esa serta berakhlak mulia.

Pembahasan tentang pembelajaran Pendidikan Agama Islam terkait erat dengan sikap keberagamaan seseorang (religiusitas). Sikap keberagamaan bukan sekedar pengetahuan, tetapi juga ketundukan dan ketaatan, atau dengan kata lain, pengetahuan yang membuahkan ketaatan (pemahaman dan pengamalan agama). Dengan demikian Pendidikan Agama Islam sangat berperan sekali dalam membentuk manusia yang beriman dan bertakwa kepada Allah dengan mengamalkan ajaran agama dalam setiap kehidupan pribadi, bermasyarakat berbangsa dan bernegara.

\section{Sekolah Berbasis Pesantren}

Menurut Rusdy (2016), sejarah kelahiran SBP berawal dari inisiatif dan tantangan Direktur SMP, Hamid Muhammad, Ph.D kepada Tim Center for Research and Development in Education pada awal tahun 2007. Wacana ini kemudian dikonkretkan dalam bentuk workshop dan feasibility studi di tahun 2007-2008 serta penyusunan pedoman penyelenggaraan program SBP. Pada awalnya SBP akan dilaksanakan dalam bentuk piloting di 5 lokasi, namun berubah karena Hamid Muhammad, Ph.D dipromosikan menjadi Dirjen Pendidikan Luar Sekolah (PLS), sehingga MoU baru terjadi pada tahun 2008 setelah konsep pengembangan SBP tersusun sebagai strategi untuk keberlanjutan program SBP.

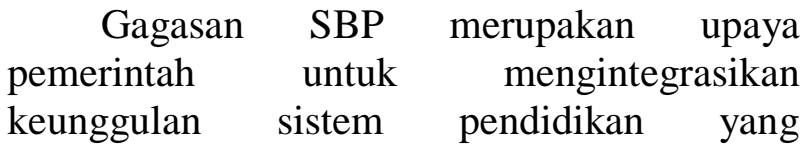
dikembangkan di sekolah formal dengan keunggulan sistem pendidikan yang dilaksanakan di pesantren (Suyanto and Suhardi, 2014). Dalam pelaksanaannya, sekolah berbasis pesantren merupakan model pendidikan integratif yang menggabungkan pelaksanaan sistem persekolahan yang mengembangkan kemampuan sains dan keterampilan dengan pelaksanaan sistem pesantren yang mengembangkan sikap dan praktik keagamaan, peningkatan moralitas dan kemandirian dalam hidup. 
Sekolah dan pesantren merupakan dua satuan pendidikan yang memiliki keunggulan berbeda. Bila mereka berjalan sendiri-sendiri, ada potensi dan kekuatan pendidikan yang terbuang sia-sia. Bila keduanya dapat disatukan akan lahir sebuah kekuatan pendidikan yang komprehensif. Proses pendidikan di sekolah mencakup beberapa dimensi: 1) pendidikan (sikap, pengetahuan dan keterampilan, 2) peran seleksi sosial yang mencakup pemberian legalitas (ijazah/sertifikat) dan seleksi terhadap peluang kerja, 3) pembinaan peserta didik, dan 4) aktivitas kemasyarakatan.

Sekolah memiliki keunggulan dalam pengembangan peserta didik karena didukung oleh sistem berjenjang, program didesain secara hierarki dan sistematis, serta adanya standarisasi pencapaian keberhasilan pendidikan. Peserta didik juga mendapatkan materi terstruktur, faktual dan dibutuhkan dalam dunia kerja, sehingga sekolah memberikan kontribusi bagi pembentukan dan pengembangan SDM berkualitas. Sekolah menjadi barometer untuk menyebutkan seseorang berpendidikan atau tidak.

Keunggulan lain sistem sekolah adalah: 1) kurikulum yang dinamis dan fleksibel ditandai dengan bahan ajar yang disusun secara sistematis sesuai dengan kompetensi yang ingin dicapai, strategi dan model pembelajaran variatif yang berorientasi pada efektivitas dan efisiensi; 2) pendidik memiliki kualifikasi dan kompetensi yang terukur; 3) sarana dan prasarana lebih memadai; dan 4) manajemen yang lebih profesional.

Di samping sekolah, pesantren dikenal sebagai salah satu lembaga pendidikan Islam asli dan tertua di Indonesia. Pesantren adalah dimensi pendidikan yang memiliki elemenelemen penunjang yang khas, baik elemen yang bersifat hardware seperti: masjid, pondok, ruang belajar, kitab-kitab dan lain sebagainya. Selain itu pesantren mempunyai elemen yang bersifat software, seperti: tujuan pendidikan, kurikulum, metode pengajaran, sistem evaluasi dan perangkat lainnya yang menunjang proses belajar mengajar (Fatah, Taufik and Bisri, 2005).

Menurut Iskandar (2010) pesantren memiliki berbagai keunggulan, antara lain: 1) misi pendidikan lebih banyak ditekankan pada aspek moralitas dan pembinaan kepribadian; 2) kultur kemandirian dalam interaksi sosial; 3) penguasaan literatur klasik yang sarat dengan nilai dan pesan moral yang berguna bagi pengembangan peradaban yang beretika; 4) kharisma kiai sebagai manajer dan pengasuh lembaga pesantren menjadikan panutan dan teladan dalam kehidupan sehari-hari; dan 5) hubungan kiai dan santri yang bersifat kekeluargaan dengan kepatuhan yang tinggi.

Keunggulan pada masing-masing satuan pendidikan tersebut akan semakin berarti, jika keduanya diintegrasikan ke dalam satu model satuan pendidikan yang dikelola secara terpadu. Prinsip dasar SBP adalah pengintegrasian berbagai kecerdasan sebagai upaya pembentukan multiple intelegence peserta didik agar memiliki kemampuan akal (pikir), kemampuan spiritual (zikir dan qalbu), dan kemampuan untuk melakukan sesuatu atas dasar keterampilan dan profesionalitas.

Secara umum pendidikan SBP ini bertujuan untuk mengintegrasikan sistem pendidikan yang dikembangkan di sekolah dengan sistem pendidikan yang dilaksanakan di pesantren. Secara detail, tujuan pelaksanaan SBP ini adalah (1) melaksanakan model pengembangan pendidikan yang integratif dan komprehensif dalam peningkatan mutu sumber daya manusia Indonesia; (2) mengembangkan model pendidikan yang berorientasi pada keunggulan komparatif (comparative advantages) dan keunggulan kompetitif (competitive advantages) dalam menghadapi persaingan global; (3) meningkatkan mutu sumber daya manusia yang memiliki keseimbangan intelektual quotient, emotional quotient dan spiritual quotient; (4) mengembangkan model pendidikan yang berwatak plural dan multikultular, kesetaraan gender dan demokratis.

Berdasarkan pada tujuan tersebut, maka hasil yang diharapkan dari pelaksanaan pendidikan Sekolah Berbasis Pesantren ini adalah (a) terdapat rumusan dan desain model pengembangan pendidikan yang integratif dan komprehensif bagi peningkatan mutu sumber daya manusia; (b) adanya sistem pendidikan yang terstandar yang berorientasi pada pengembangan keunggulan komparatif 
(comparative advantages) dan keunggulan kompetitif (competitive advantages) dalam menghadapi persaingan global; (c) terjadinya peningkatan mutu sumber daya manusia yang memiliki keseimbangan intelektual quotient, emotional quotient dan spiritual quotient; (d) terbentuknya kepribadian sumber daya manusia Indonesia yang berwatak pluralis, nasional dan multikulturalis (Tim Pelaksana Workshop, 2017).

Dalam aplikasinya sekolah berbasis pesantren diartikan sebagai sekolah yang menerapkan pendekatan penyelenggaraan dengan memadukan pendidikan umum dan pendidikan agama menjadi satu jalinan kurikulum. Dengan pendekatan ini, semua mata pelajaran dan semua kegiatan sekolah tidak lepas dari bingkai ajaran dan pesan nilai Islam. Tidak ada dikotomi, tidak ada keterpisahan, semua bahasan tidak terlepas dari nilai dan ajaran Islam. Pelajaran umum, seperti matematika, IPA, IPS, bahasa, jasmani/kesehatan, keterampilan dibingkai dengan pijakan, pedoman dan panduan Islam. Sementara dalam pemahaman ilmu agama Islam, sekolah berbasis pesantren diperkaya dengan adanya kurikulum kepesantrenan.

Sekolah berbasis pesantren menekankan keterpaduan dalam metode pembelajaran sehingga dapat mengoptimalkan ranah kognitif, afektif dan konotif. Implikasi dari keterpaduan ini menuntut pengembangan pendekatan proses pembelajaran yang kaya, variatif dan menggunakan media serta sumber belajar yang luas dan luwes. Metode pembelajaran menekankan penggunaan dan pendekatan yang memicu dan memacu optimalisasi pemberdayaan otak kiri dan otak kanan.

Sekolah berbasis pesantren juga memadukan pendidikan aqliyah, ruhiyah dan jasadiyah. Artinya, berupaya mendidik peserta didik menjadi anak yang berkembang kemampuan akal dan intelektualnya, meningkat kualitas keimanan dan ketakwaannya kepada Allah SWT, terbina akhlak yang berbudi mulia (Temulus, 2015).

\section{METODE PENELITIAN}

Penelitian ini merupakan bagian dari penelitian studi kasus. Menurut Bogdan dan
Biklen dalam Widodo dan Mukhtar (2000), studi kasus merupakan pengujian secara rinci terhadap satu latar atau satu orang subjek atau satu tempat penyimpanan dokumen atau satu peristiwa tertentu. Sedangkan menurut Arikunto, studi kasus sebagai salah satu jenis pendekatan deskriptif, penelitian yang dilakukan secara intensif, terperinci, dan mendalam terhadap suatu organisme (individu), lembaga atau gejala tertentu dengan daerah atau subjek yang sempit (Gunawan, 2013).

Alasan peneliti menggunakan jenis penelitian studi kasus karena dalam penelitian ini obyek yang diamati adalah suatu kasus yang istimewa dan memiliki keunikan tersendiri, yaitu menggambarkan penyelenggaraan Pendidikan Agama Islam di SMP Al Muttaqin Kota Tasikmalaya yang sudah berhasil dalam mengembangkan program SBP. Dalam hal ini peneliti langsung terjun ke lapangan di mana penelitian dilaksanakan, kemudian melakukan pendekatan terhadap orang-orang yang akan dijadikan sumber informasi, sehingga dapat diperoleh data-data secara keseluruhan baik lisan maupun tulisan (Yin, 2008).

Pengumpulan data dilakukan melalui teknik observasi, wawancara dan studi dokumentasi. Observasi dilakukan dengan melakukan kunjungan langsung ke SMP Al Muttaqin yang menjadi sasaran penelitian untuk melakukan pengamatan, baik terhadap proses pembelajaran PAI yang berlangsung maupun sarana pembelajaran yang tersedia. Wawancara dilakukan terhadap sejumlah narasumber baik pihak sekolah (kepala sekolah dan guru PAI dan tenaga pengajar lainnya) maupun pengurus pesantren (kiai dan wali asrama) dan instansi terkait (Dinas Pendidikan dan Kasi PD Pontren Kota Tasikmalaya). Studi dokumentasi dilakukan terhadap berbagai sumber informasi relevan, termasuk data-data mengenai prestasi akademik, jumlah siswa dan jumlah sarana pembelajaran.

Teknik analisis data yang digunakan mengikuti alur analisis data kualitatif Miles dan Huberman yang meliputi: 1) reduksi data, 2) penyajian data, dan 3) penarikan kesimpulan dan verifikasi (Draper, 2008). Reduksi data adalah tahap menyeleksi, memfokuskan, 
menyederhanakan, mengabstraksikan dan mentransformasikan data yang muncul dalam catatan lapangan atau transkrip wawancara. Selanjutnya adalah tahap penyajian data, baik dalam bentuk tabel, diagram atau gambar. Tahap terakhir, penarikan kesimpulan dan verifikasi, adalah proses untuk membuat keputusan tentang makna dari data yang telah diperoleh, terkait kelaziman (regularities), pola (patterns), penjelasan (explanations), alur sebab-akibat (causal flows) serta proposisiproposisi yang mungkin diajukan berdasarkan data yang diperoleh. Termasuk di dalam tahap ini adalah proses untuk menguji atau mengecek kembali kesahihan data yang diperoleh, kelogisan argumen yang dikembangkan, dan ketepatan kesimpulan yang ditarik. Seluruh data yang telah terkumpul diolah dan dianalisis untuk menghasilkan gambaran deskriptif menyangkut aspek Pendidikan Agama Islam di SMP Al Muttaqin. Dengan analisis demikian, diharapkan penelitian ini akan melahirkan kesimpulan berupa proposisi-proposisi yang berkaitan dengan tujuan penelitian.

\section{HASIL DAN PEMBAHASAN}

\section{Selayang Pandang SMP Al Muttaqin}

SMP Al Muttaqin berkedudukan di Jalan Jenderal Ahmad Yani Nomor 140 Kelurahan Sukamanah Kecamatan Cipedes Kota Tasikmalaya Provinsi Jawa Barat. Berdasarkan hasil wawancara, SMP-Al Muttaqin terbentuk pada tanggal 21 Juli 2000. Bermula dari animo masyarakat dan orang tua murid yang menyekolahkan anaknya di SD Al Muttaqin, para orang tua berpendapat jika SMP Al Muttaqin didirikan, mereka akan meneruskan anak-anaknya ke SMP Al Muttaqin. Berdasarkan animo tersebut dibentuklah tim pendirian SMP Al Muttaqin yang beranggotakan H. Ade H., Yayan Sopyan dan Tabi'in Baedlowi (Dr. H. D. Suryatman, M.Si [Pengurus Yayasan Al Muttaqin], Wawancara, 20 Mei 2016).

SMP Al Muttaqin menggunakan sistem full day school, yaitu kegiatan pembelajaran dilakukan sepanjang hari dari pukul 07.30 hingga pukul 15.30. Pada tahun pertama menerima 3 kelas dan Kegiatan Belajar Mengajar (KBM) untuk sementara menumpang di SD Al Muttaqin. Setelah gedung SMP Al Muttaqin selesai KBM pindah ke Jalan Ahmad Yani No. 140. Pada awalnya SMP Al Muttaqin akan dibangun di kawasan Tirta Alam, tetapi mendapat larangan dari TNI AURI karena dapat menghalangi radar jika ada pesawat mendarat.

Berdirinya SMP Al Muttaqin Tasikmalaya merupakan refleksi dari komitmen Yayasan Al Muttaqin terhadap salah satu misinya, yaitu ikut serta menyediakan sumber daya manusia yang berkualitas melalui penyelenggaraan satuan pendidikan pada jalur sekolah sejak pendidikan pra sekolah hingga pendidikan tinggi, serta pendidikan jalur luar sekolah seperti majelis taklim, pondok pesantren dan kursus kursus (Profil Yayasan Almuttaqin, Anggaran Dasar, Pasal 3).

SMP Al Muttaqin memiliki visi "unggul dan terdepan dalam prestasi berlandaskan iman dan takwa". Visi tersebut kemudian dijabarkan dalam bentuk misi sebagai berikut: (1) mewujudkan penghayatan dan pengalaman agama dengan mengembangkan sikap toleransi; (2) mewujudkan kurikulum sekolah sesuai dengan standar isi; (3) mewujudkan proses pembelajaran yang berkualitas dengan berbagai variasi pendekatan, metode, teknik dan strategi pembelajaran (student centered, learning, active learning, enjoyable and joyful learning, cooperative learning, quantum learning, learning revolution, contectual learning) untuk memperoleh rerata nilai lulusan yang bertaraf internasional; (4) mewujudkan pendidik dan tenaga kependidikan sesuai standar isi; (5) mewujudkan seluruh sarana prasarana yang berbasis IT; (6) mewujudkan sistem dan tata kelola sekolah yang menjamin keterlaksanaan dan keberhasilan manajemen sebagai sekolah efektif; (7) mewujudkan standar penilaian yang dapat menjamin dan mengembangkan mutu pendidikan; (8) mewujudkan tumbuh kembangnya sikap ilmiah dengan mengoptimalkan kegiatan penelitian ilmiah berbasis teknologi; (9) mewujudkan tumbuh kembangnya rasa cinta terhadap seni dan budaya daerah, peningkatan kreativitas dan apresiasi terhadap bidang seni budaya dalam kerangka wawasan lintas budaya; (10) mewujudkan tumbuh kembangnya potensi dan capaian prestasi bidang olah raga serta kultur 
kompetitif dan sportivitas; (11) mewujudkan lingkungan sekolah yang menghargai keberagaman dan demokrasi; (12) mewujudkan lingkungan sekolah yang bersih, indah dan hijau serta menumbuh kembangkan sikap peduli lingkungan; (13) mewujudkan lingkungan sekolah yang berakhlakul karimah.

\section{Peserta Didik}

Pada tahun pelajaran 2015-2016 SMP Al Muttaqin memilik 657 siswa, terdiri dari 358 laki-laki dan 299 perempuan yang disebar ke dalam 21 rombongan belajar (Tbel 1).

Tabel 1. Data peserta didik SMP Al Muttaqin tahun pelajaran 2015-2016

\begin{tabular}{ccllc}
\hline \multirow{2}{*}{ No } & \multirow{2}{*}{ Kelas } & \multicolumn{1}{c}{ Nama kelas } & Jumlah siswa \\
& & L & P \\
\hline 1 & $7 \mathrm{~A}$ & Khadijah Binti Khuwalid & & 31 \\
2 & $7 \mathrm{~B}$ & Ahmad Bin Hambal & & 34 \\
3 & $7 \mathrm{C}$ & Muhammad Bin Abdul Wahab & & 31 \\
4 & $7 \mathrm{D}$ & Ibnu Taimiyyah & 32 & \\
5 & $7 \mathrm{E}$ & Ali Bin Abi Thalib & 33 & \\
6 & $7 \mathrm{~F}$ & Umar Bin Khatab & 29 & \\
7 & $7 \mathrm{G}$ & Aisyah Binti Abu Bakar & 31 & \\
8 & $8 \mathrm{~A}$ & Ibnu Qoyyim Al-Jauzi & & 31 \\
9 & $8 \mathrm{~B}$ & Jamaludin Al Afghani & & 28 \\
10 & $8 \mathrm{C}$ & Abu Bakar Siddiq & & 30 \\
11 & $8 \mathrm{D}$ & Usman Bin Affan & 33 & \\
12 & $8 \mathrm{E}$ & Bilal Bin Rabah & 34 & \\
13 & $8 \mathrm{~F}$ & Ummu Salamah & 34 & \\
14 & $8 \mathrm{G}$ & Ja'far Bin Abi Thalib & 33 & \\
15 & $9 \mathrm{~A}$ & Muhammad Rasyid Ridha & & 29 \\
16 & $9 \mathrm{~B}$ & Hasan Al-Banna & & 29 \\
17 & $9 \mathrm{C}$ & Sayyid Qutb & & 29 \\
18 & $9 \mathrm{D}$ & hafsah Binti Abu Bakar & 32 & \\
18 & $9 \mathrm{E}$ & Abu Khurairah & 33 & \\
20 & $9 \mathrm{~F}$ & Abbas Bin Abdul Muthalib & 358 & 299 \\
21 & $9 \mathrm{G}$ & Salahuddin Al Ayubi & & \\
& & Jumlah & 34 \\
\hline
\end{tabular}

Sumber: Wakasek Kesiswaan SMP Al Muttaqin (2016)

Berdasarkan data di atas, SMP Al Muttaqin melakukan pemisahan kelas berdasarkan jenis kelami, 10 kelas untuk rombel perempuan dan 11 kelas untuk rombel laki-laki. Dari 657 jumlah siswa, hanya 213 siswa yang berstatus sebagai santri mukim, sisanya pulang pergi. Sebenarnya minat untuk mondok sangat banyak, namun karena keterbatasan sarana dan prasarana pondok, untuk sementara ini asrama atau pondok hanya diperuntukkan untuk siswa yang jaraknya jauh dari sekolah.

Pemisahan kelas siswa dengan kelas siswi dilakukan untuk mencegah terjadinya fitnah dan pergaulan bebas yang tidak diharapkan, karena Islam sangat menjaga pergaulan laki-laki dan wanita yang bukan mahram, juga agar siswa-siswi di dalam proses pembelajaran lebih fokus dan termotivasi juga menjaga pergaulan antara laki-laki dan perempuan (Taqiyah, 2016). Pada awalnya pemberlakuan pemisahan kelas laki-laki dan perempuan di SMP Al Muttaqin menuai beberapa kecaman, karena kebijakan tersebut dinilai tidak efektif dan memasung interaksi sosial remaja. Namun setelah melihat hasil dari proses pemisahan tersebut sebagian besar dari mereka yang mengecam menyetujuinya (Yayan Sofyan, S.Ag., M.Pd.I [Kepala SMP Al Muttaqin] Wawancara, 2 Mei 2016).

Di samping pemisahan kelas antara perempuan dan laki-laki, SMP Al Muttaqin juga menggunakan nama-nama sahabat nabi dan tokoh-tokoh Islam sebagai simbol 
penamaan kelas. Hal ini bertujuan untuk mengenalkan kepada peserta didik terkait khitah dan perjuangan sahabat dan tokoh Islam tersebut. Karena mendalami dan mempelajari kisah-kisah salafush shalih (generasi awal Islam) akan serasa mengarungi lautan yang tak bertepi, bahkan berbagai keunikan dan fenomena hidup telah mereka jalani bisa kita teladani atau bisa diambil ibrah (pelajaran)
(KH. Ujang Mulyana, S.Pd.I., al-Hafiz [Pimpinan Pondok Pesantren Al Muttaqin] Wawancara, 19 Mei 2016).

\section{Tenaga Pendidik dan Kependidikan.}

SMP Al Muttaqin memiliki 65 sumber daya manusia dalam menjalankan misi lembaga di atas (Tabel 2).

Tabel 2. Data tenaga pendidik dan kependidikan SMP Al Muttaqin tahun pelajaran 2015-2016

\begin{tabular}{clccc}
\hline No & Pegawai & Tetap yayasan & Honor yayasan & Jumlah \\
\hline 1 & Guru & 27 & 28 & 55 \\
2 & Tata Usaha & 2 & 2 & 4 \\
3 & Pustakawan & & 1 & 1 \\
4 & Pramubakti & 3 & 1 & 4 \\
5 & Satpam & 1 & & 1 \\
& Jumlah & 33 & 32 & 65 \\
\hline
\end{tabular}

Sumber: Wakasek Kurikulum (2016).

Berdasarkan jenjang pendidikan, hampir semua guru di SMP Al Muttaqin sudah menyelesaikan S1, bahkan ada beberapa guru yang sudah menempuh jenjang pendidikan S2. Khusus untuk guru PAI berjumlah 3 orang, dibantu guru Alquran 3 orang dan pendampingan bahasa 7 orang.

\section{Sarana dan Prasarana}

Berdasarkan hasil observasi, sarana prasarana yang tersedia di SMP Al Muttaqin relatif lengkap dengan bangunan yang megah sebagaimana terlihat pada gambar (1) di bawah ini. 16 ruang belajar berjumlah, 1 perpustakaan, 1 laboratorium IPA ditambah dengan beberapa ruang kantor untuk kepala sekolah, wakasek, guru, tata usaha dan tamu. Pada setiap ruang kelas dipajang beberapa gambar atau ditulis kalimat-kalimat yang mengandung unsur motivasi yang diambil dari ayat suci Alquran atau hadis Nabi. Selain bangunan sekolah, SMP Al Muttaqin juga bangunan pesantren secara terpisah dan megah (gambar 2). Sayangnya bangunan pesantren ini belum bisa menampung seluruh siswa, sehingga penghuni asrama masih menggunakan sistem seleksi, dan diutamakan bagi siswa yang jaraknya jauh dari sekolah. Padahal minat siswa untuk tinggal di pondok sangat tinggi (KH. Ujang Mulyana, S.Pd.I., alHafiz [Pimpinan Pondok Pesantren Al Muttaqin] Wawancara, 19 Mei 2016).

\section{Pendidikan Agama Islam Pada SMP Al Muttaqin}

\section{Pengembangan Struktur Kurikulum PAI}

Undang-Undang Nomor 20 tahun 2003 pasal 1 menyatakan bahwa kurikulum adalah seperangkat rencana dan pengaturan mengenai tujuan, isi dan bahan pelajaran serta cara yang digunakan sebagai pedoman penyelenggaraan kegiatan pembelajaran untuk mencapai tujuan pendidikan tertentu. Dengan kata lain kurikulum adalah seperangkat rencana pengajaran yang digunakan guru sebagai pedoman dalam kegiatan belajar mengajar di sekolah untuk mencapai tujuan Pendidikan.

Pengertian kurikulum dalam pandangan modern merupakan program pendidikan yang disediakan oleh sekolah yang tidak hanya sebatas bidang studi dan kegiatan belajarnya saja, akan tetapi meliputi segala sesuatu yang dapat mempengaruhi perkembangan dan pembentukan pribadi siswa sesuai dengan tujuan pendidikan yang diharapkan sehingga dapat meningkatkan mutu kehidupannya yang pelaksanaannya tidak hanya di sekolah tetapi juga di luar sekolah.

Jika diaplikasikan dalam PAI, maka kurikulum berfungsi sebagai pedoman yang digunakan oleh pendidik untuk membimbing peserta didiknya ke arah tujuan tertinggi pendidikan Islam, melalui akumulasi sejumlah pengetahuan, keterampilan dan sikap. Dalam 
hal ini proses pendidikan Islam bukanlah suatu proses yang dapat dilakukan secara serampangan, tetapi hendaknya mengacu kepada konseptualisasi manusia paripurna (insan kamil) yang strateginya telah tersusun secara sistematis dalam kurikulum PAI pada SBP (Aulia, 2016).

Aplikasi di lapangan penyelenggaraan PAI di sekolah pada umumnya sangat penuh dengan tantangan, karena beban pelajaran yang di ampu cukup padat, materi juga memerlukan banyak pengayaan. Sementara itu, waktu yang di alokasikan untuk tatap muka secara formal sangat singkat. Padahal muatan utama pendidikan agama adalah proses internalisasi nilai yang memerlukan kerapatan pengulangan dan kesinambungan. Oleh karena itu, perlu adanya kebijakan khusus dari sekolah dan upaya dari tenaga pendidik untuk mengembangkan pola pembelajaran yang efektif dan efisien sehingga ketuntasan belajar dapat tercapai, khususnya kurikulum mikro PAI di sekolah bisa tercapai.

Menyadari betapa pentingnya posisi PAI dalam membina akhlak mulia peserta didik, SMP Al Muttaqin melakukan sebuah terobosan dengan melakukan pengembangan struktur kurikulum PAI ke dalam beberapa sub pembelajaran seperti tertera dalam tabel 3 .

Tabel 3. Struktur kurikulum SMP Al Muttaqin tahun pelajaran 2015-2016

\begin{tabular}{clc}
\hline No. & \multicolumn{1}{c}{ Komponen mata pelajaran } & SMP Al Muttaqin \\
\hline 1. & Pendidikan Agama & 1 \\
2. & Pendidkan Kewarganagaraan & 1 \\
3. & Bahasa Indonesia & 4 \\
4. & Bahasa Inggris & 6 \\
5. & Matematika & 4 \\
6. & Ilmu Pengetahuan Alam & 4 \\
7. & Ilmu Pengetahuan Sosial & 2 \\
8. & Seni Budaya & 2 \\
9. & Pendidkan Jasmani dan kesehatan & 2 \\
10. & Teknologi Informatika dan Komunikasi & 2 \\
11. & Bahasa Sunda & 1 \\
12. & Bahasa Arab & 2 \\
13. & Jasa Boga/Prakarya & 2 \\
14. & BTQ/Tahfiz & 8 \\
15. & Flqih & 2 \\
16. & Aqidah & 1 \\
17. & SKI & 1 \\
18. & Kepesantrenan & \\
19. & Pengembangan Diri & 3 \\
20. & Pendidikan Lingkungan Hidup & 47 \\
Jumlah Jam & & \\
\hline
\end{tabular}

Sumber: Dokumen kurikulum (2016)

Pengembangan kurikulum PAI ialah kegiatan menghasilkan kurikulum PAI dengan mengaitkan satu komponen dengan komponen lainnya berupa kegiatan penyusunan (Desain), pelaksanaan, penilaian dan penyempurnaan kurikulum PAI untuk menghasilkan kurikulum PAI yang lebih baik (Muhaimin, 2012) Berdasarkan tabel di atas, SMP Al Muttaqin mengembangkan mata pelajaran PAI ke dalam Bahasa Arab, Tahfiz, Fiqih dan SKI. Pengembangan kurikulum tersebut dimaksudkan untuk pendalaman dan penguatan iman dan takwa peserta didik, juga sebagai bekal persiapan menuju jenjang pendidikan selanjutnya, karena setiap tahun hampir $100 \%$ alumni SMP Al Muttaqin melanjutkan pada lembaga pendidikan di atasnya.

Selain itu, yang paling penting adalah penerapan budaya kepesantrenan yang masuk dalam muatan kurikulum. SMP Al Muttaqin melakukan hal tersebut dengan mempertimbangkan pendidikan sebagai proses 
sosialisasi melalui interaksi insani menuju manusia yang berbudaya. Dalam konteks inilah anak didik dihadapkan dengan budaya manusia, dibina dan dikembangkan sesuai dengan nilai budaya pesantren, serta dipupuk kemampuan dirinya menjadi manusia. Realitas sosial-budaya dan agama dalam kehidupan masyarakat merupakan bahan dasar dalam kajian penyusunan, perkembangan kurikulum di SMP Al Muttaqin (Yayan Sofyan, S.Ag., M.Pd.I [Kepala SMP Al Muttaqin], Wawancara, 2 Mei 2016).

\section{Implementasi Agama Islam \\ Pembelajaran Pendidikan}

Pada tataran implementasinya, SBP merupakan model pendidikan unggulan yang mengintegrasikan pelaksanaan sistem persekolahan yang menitikberatkan pada pengembangan kemampuan sains dan keterampilan dengan pelaksanaan sistem pesantren yang menitikberatkan pada pengembangan sikap dan praktik keagamaan, peningkatan moralitas dan kemandirian dalam hidup.

Perubahan sosial ini mengacu pada perubahan sistem sosial dan budaya yang memadukan sistem pendidikan sekolah dan sistem pendidikan pesantren, sehingga meluluskan ilmuwan yang agamawan. SMP Al Muttaqin memadukan sistem pendidikan di sekolah formal dan di pondok pesantren, ini dikembangkan setelah melihat dan mengamati secara seksama mutu pendidikan yang dilahirkan oleh masing-masing sistem.

Pembelajaran pada hakikatnya merupakan proses komunikasi transaksional yang bersifat timbal balik, antara guru dengan siswa, siswa dengan siswa untuk mencapai tujuan yang telah ditetapkan. Komunikasi transaksional adalah bentuk komunikasi yang dapat diterima, dipahami dan disepakati oleholeh pihak-pihak yang terkait dalam proses pembelajaran sehingga menunjukkan adanya perolehan, penguasaan, hasil, proses atau fungsi.

Mekanisme pembelajaran di SMP Al Muttaqin secara umum meliputi: a) Tahap persiapan; persiapan proses pembelajaran yang menyangkut penyusunan desain (rancangan) kegiatan belajar mengajar yang akan diselenggarakan, di dalamnya meliputi: tujuan, metode, media, sumber, evaluasi dan kegiatan belajar siswa; b) Tahap pelaksanaan; pelaksanaan proses pembelajaran menggambarkan dinamika kegiatan belajar siswa yang dipandu dan dibuat dinamis oleh guru; c) Tahap evaluasi; evaluasi merupakan laporan dari proses pembelajaran, khususnya laporan tentang kemajuan dan prestasi belajar siswa dan; d) Tahap refleksi; tindak lanjut dalam proses pembelajaran dapat dipilah menjadi dua hal, yaitu promosi dan rehabilitasi. Promosi adalah penetapan untuk melangkah dan peningkatan lebih lanjut atas keberhasilan siswa, sedangkan rehabilitasi adalah perbaikan atas kekurangan yang telah terjadi dalam proses pembelajaran.

Dalam tahap perencanaan, guru-guru SMP Al Muttaqin telah mencoba memasukkan nilai-nilai kultur kepesantrenan ke dalam dokumen silabus dan Rencana Pelaksanaan Pembelajaran (RPP), namun terkendala ketika ada supervisi dari pengawas. Karena model dokumen pembelajaran tersebut dianggap "aneh", sehingga harus direvisi atau dibuat ganda. Hal tersebut sangat memberatkan bagi guru, mengingat keterbatasan waktu yang tersedia di samping beban kerja yang cukup berat dan padat serta menguras tenaga dan pikiran. Sehingga model administrasi pembelajaran yang dibuat dan digunakan di SMP Al Muttaqin kembali kepada konsep semula, dengan desain yang umum (Koentoro Panca Nada, S.Pd. M.Pd.I [Guru SMP Al Muttaqin], Wawancara, 2 Mei 2016).

Secara umum, kultur dalam bahasa Indonesia dikenal dengan budaya. Sistem pondok pesantren memiliki kultur yang unik, setidaknya ada 17 kultur kepesantrenan: 1) pendalaman ilmu agama; 2) mondok; 3) kepatuhan; 4) keteladanan; 5) kesalehan; 6) kemandirian; 7) kedisiplinan;

kesederhanaan; 9) toleransi; 10) qonaah; 11) rendah hati; 12) ketabahan; 13) kesetiakawanan/tolong menolong; 14) ketulusan; 15) istiqamah; 16) kemasyarakatan; dan 17) kebersihan (Sayuti and Fauzan, 2012). Dari 17 kultur kepesantrenan yang sudah kelihatan dominan di SMP Al Muttaqin adalah kultur pendalaman ilmu agama dan kultur kebersihan. Kultur kebersihan terlihat dari 
lingkungan sekolah yang bersih, ruang kelas dan sarana prasarana lainnya yang bersih, kesadaran membuang sampah pada tempatnya dan adanya budaya pembiasaan hidup bersih disekolah.

Kultur pendalaman ilmu agama terlihat dari semangat menghafal Alquran. Untuk menyukseskan program tahfiz Alquran SMP Al Muttaqin melakukan beberapa strategi dalam proses pembelajaran: 1) sebelum kegiatan KBM berlangsung dilakukan tadarus bersama, bahkan untuk tahun pelajaran baru, untuk dua jam pertama di khususkan untuk pelajaran tahfiz; 2) setiap pergantian jam pelajaran diawali dengan tadarus surat yang sedang di hafal pada waktu itu; 3) saat pelajaran olah raga, proses pemanasan diawali dengan hafalan Alquran dan 4) dalam proses upacara, sesudah pembacaan ikrar dan sebelum pembacaan doa dilakukan pembacaan ayatayat suci Alquran yang sedang dihafal. Berikut salah satu contoh dokumen kegiatan tahfiz Alquran.

Untuk mengontrol hafalan peserta didik, SMP Al Muttaqin membuat buku catatan tahfiz Alquran sebagai sarana evaluasi. Buku tersebut dibawa setiap kali hendak setor hafalan dan setiap kali akhir semester diadakan ulangan hapalan. Indikator keberhasilan siswa dibuktikan dengan capaian target berikut ini: 1) lancar dan fasih membaca Alquran; 2) hafal dan paham juz 30 dan 29; 3) hafal ayat-ayat pilihan sesuai dengan materi ajar di sekolah dan mulai tahun ajaran baru target hafalan bertambah dari 2 juz menjadi 5 juz. (Yayan Sofyan, S.Ag., M.Pd.I [Kepala Sekolah Al Muttaqin], Wawancara, 2 Mei 2016).

Kepala Sekolah SMP Al Muttaqin selaku penanggung jawab dalam proses KBM senantiasa mengingatkan kepada semua warga sekolah tanpa kecuali untuk mengimplementasikan keimanan dan ketakwaan mulai dari Kepala Sekolah, Wakil Kepala Sekolah, Guru, TU, Karyawan Sekolah dan segenap peserta didik. Hal ini dimaksudkan agar tercipta suasana yang religius. Di samping itu, untuk menunjang keberhasilan pendidikan, terutama dalam hal akhlak mulia menurut dilakukan pengayaan melalui kegiatan ekstra kurikuler bernuansa agama.
Baik dalam proses pembelajaran PAI maupun pelajaran yang lainnya, SMP $\mathrm{Al}$ Muttaqin berpedoman kepada BSNP. Untuk menunjang proses pembelajaran dilakukan kegiatan-kegiatan seperti pengembangan metode pembelajaran PAI, pengembangan kultur budaya Islami dalam proses pembelajaran, dan pengembangan kegiatankegiatan kerohanian Islam seperti Peringatan Hari Raya Besar Islam (PHBI), pengelolaan zakat, penyembelihan hewan kurban dan lainlain. Sementara itu, sebagai acuan kurikulum dalam pembelajaran menggunakan Kurikulum 2013 yang berbasis Pendidikan Budaya Karakter Bangsa, termasuk di dalamnya Kurikulum PAI.

Upaya pemantapan, pengayaan dan perbaikan nilai-nilai, norma serta pengembangan bakat, minat dan kepribadian peserta didik dalam aspek pengamalan, keimanan, ketakwaan, akhlak mulia, ibadah, sejarah, seni dan kebudayaan, SMP Al Muttaqin melakukan program keagamaan yang dikemas dalam tradisi "teladan" atau "pembiasaan" seperti: absus salam, berdoa sebelum pembelajaran dimulai, tadarus Alquran, salat duha, kultum, zuhur berjamaah, gerakan infaq jumat, gerakan berbusana muslim serta bakti sosial.

\section{Implikasi Pengembangan Kurikulum Pendidikan Agama Islam}

Pendidikan Agama Islam di SMP Al Muttaqin selain sebagai instrumen bagi pengembangan dan peningkatan perilaku ubudiyah siswa juga dijadikan sebagai salah satu mata pelajaran yang memiliki fungsi bagi pembinaan kepribadian, akhlak dan perilaku siswa di sekolah. Keberadaannya menjadi sangat signifikan dalam konteks menekan perilaku-perilaku deviatif dan gaya hidup hedonis siswa di sekolah.

Hasil pelaksanaan pembelajaran PAI di SMP Al Muttaqin termasuk baik dan patut diapresiasi. Hal ini bisa dilihat dari segi nilai mata pelajaran baik pemahaman materi maupun sikap. Di samping itu dampak pemahaman dan sikap sebagai implementasi dari pembelajaran PAI berkorelasi terhadap animo masyarakat dalam memasukkan anaknya ke SMP Al Muttaqin (Tabel 4). 
Tabel 4. Animo masyarakat menyekolahkan ke SMP Al Muttaqin

\begin{tabular}{cccc}
\hline No. & Tahun pelajaran & Pendaftar & Diterima \\
\hline 1 & $2011 / 2012$ & 250 & 164 \\
2 & $2012 / 2013$ & 255 & 198 \\
3 & $2013 / 2014$ & 260 & 229 \\
4 & $2014 / 2015$ & 270 & 228 \\
5 & $2015 / 2016$ & 302 & 233 \\
\hline
\end{tabular}

Sumber: Kepala SMP Al Muttaqin (2016)

Berdasarkan data tersebut diketahui minat masyarakat untuk menyekolahkan ke SMP Al Muttaqin dalam waktu 5 tahun terakhir terus meningkat. Hal itu menunjukkan bahwa masyarakat Indonesia masih memiliki harapan yang sangat tinggi terhadap peran serta sekolah dalam konteks pengembangan kepribadian dan intelektualitas anaknya. Hal ini patut dimaklumi, mengingat pelaksanaan pendidikan di SMP Al Muttaqin diyakini memiliki keunggulan dalam konteks pengembangan sumber daya manusia, karena selain pelaksaannya yang berjenjang, juga didukung oleh adanya program pendidikan yang didesain secara hierarkis dan sistematis serta adanya standarisasi-standarisasi pencapaian keberhasilan pendidikan (Dr. H. D. Suryatman, M.Si [Pengurus Yayasan Al Muttaqin], Wawancara, 20 Mei 2016).

Model PAI di SMP Al Muttaqin tentu saja tidak dipahami sebagai sebuah "obat mujarab" atau satu satunya alternatif dalam peningkatan mutu SDM. Tetapi, paling tidak model pengembangan PAI ini dapat dijadikan sebagai kontribusi yang monumental dalam rangka mendukung pencapaian tujuan pendidikan nasional dan pengembangan manusia Indonesia yang handal, memiliki integrasi intelektual quotient dan emotional quotient serta spiritual quotient.

\section{Faktor Pendukung dan Kendala di Lapangan}

SMP Al Muttaqin sebagai bagian dari SBP merupakan model pendidikan yang mampu mengembangkan multiple intelligence (kecerdasan majemuk), spiritual-keagamaan, kecakapan hidup, dan penguatan karakter kebangsaan. SMP Al Muttaqin merupakan model sekolah yang mengintegrasikan keunggulan sistem pendidikan yang diselenggarakan di sekolah dan keunggulan "sistem" pendidikan di pesantren.
Kenyataan tersebut menunjukkan keberhasilan pelaksanaan PAI di SBP. Keberhasilan ini tidak lepas dari faktor-faktor pendukung, yaitu: Pertama, faktor sarana prasarana di SMP Al Muttaqin yang relatif lengkap, meskipun masih terbatas dalam fasilitas pondok; Kedua, faktor leadership (kepemimpinan) kepala sekolah beserta segenap jajarannya dan pimpinan pondok beserta pengurusnya yang mempunyai atensi terhadap kemajuan PAI di SMP Al Muttaqin.

Ketiga, faktor keteladanan dari guru PAI maupun guru mata pelajaran lain, sehingga pelaksanaan pembelajaran PAI dapat terlaksana dengan baik. Faktor ini menunjang pelaksanaan PAI dalam pengembangan nilainilai religiusitas. Keempat, faktor Orang tua yang mendukung pendidikan PAI di sekolah. Dukungan dari komite sekolah berupa pemberian support yang kuat dalam menciptakan nuansa sekolah yang agamis, seperti: kegiatan Ramadhan dan buka puasa bersama, salat tarawih, idul kurban. Selain itu dukungan orang tua dalam pelaksanaan karakter peduli sosial, yaitu memberikan uang infak serta zakat fitrah kepada anaknya untuk disalurkan melalui sekolah.

Sedangkan faktor-faktor yang menghambat pelaksanaan PAI adalah; Pertama, SMP Al Muttaqin memiliki keterbatasan sarana asrama atau pondok sehingga banyak menolak siswa yang berminat untuk menjadi santri "mukim". Kedua, guru PAI belum bisa ikut terlibat langsung secara maksimal dalam program peningkatan mutu yang dibiayai oleh Kemendikbud, karena dianggap "beda kamar", sehingga selama ini program pembinaan seperti workshop, bimbingan teknis ataupun pendidikan dan pelatihan lebih dominan diikuti oleh guru-guru yang mengajar mata pelajaran umun, terutama yang memegang mata pelajaran yang akan 
diikutkan Ujian Nasional. Sedangkan program pemberdayaan untuk pondok pesantren baru bisa menyentuh pembina atau wali asrama, sementara untuk pengurus asrama lainnya belum tersentuh karena keterbatasan anggaran.

\section{PENUTUP}

Berdasarkan pada temuan dan pembahasan terkait Pendidikan Agama Islam di SMP Al Muttaqin dapat disimpulkan beberapa hal sebagai berikut: Pertama, secara struktur kurikulum PAI tidak dibatasi dalam jumlah jam pelajaran yang terbatas, namun diturunkan menjadi sub bidang studi yang merupakan bagian rumpun PAI, bahkan di modifikasi dalam muatan lokal yang bernuansa khas pesantren. Kedua, Pendidikan Agama Islam di SMP Al Muttaqin tidak terbatas sebagai sebuah mata pelajaran, namun menjadi sebuah sistem sehingga tidak dibatasi ruang dan waktu yang formal.

Ketiga, SMP Al Muttaqin mempunyai keunikan dan keunggulan yaitu memprioritaskan program tahfiz Alquran dalam pengembangan PAI dengan memanfaatkan setiap waktu sebagai peluang untuk kegiatan hafalan. Keempat, implikasi dari pengembangan PAI di SMP Al Muttaqin selain dapat meningkatkan prestasi dan prestise siswa di mata orang tua dan masyarakat juga menjadikan SMP Al Muttaqin sebagai magnet dalam penerimaan peserta didik baru. Hal ini dibuktikan dengan peminat yang semakin meningkat.

Berdasarkan kesimpulan di atas, dapat direkomendasikan beberapa hal. Pertama, Kementerian Agama dan Kementerian Pendidikan dan Kebudayaan mesti mengapresiasi dan memberikan perhatian yang serius dalam bentuk reward. Baik yang bersifat materi seperti alat peraga PAI atau fasilitas asrama, mengingat hampir tiap tahun banyak menolak siswa di sebabkan keterbatasan sarana dan prasarana maupun dalam bentuk pembinaan manajemen untuk meningkatkan mutu sekolah dan mutu pesantren.

Kedua, model PAI di SMP Al Muttaqin bisa dijadikan wahana penambah wawasan dan tukar pikiran serta studi banding bagi guruguru Pendidikan Agama Islam disekolah menengah lainnya, mengingat model pembelajaran yang dikembangkan terasa lebih efektif dan efisien untuk pencapaian tujuan pendidikan. Ketiga, sebaiknya guru PAI di sekolah diberikan tugas tambahan sebagai pembina asrama, sehingga bisa ikut terlibat langsung dalam upaya peningkatan mutu pendidikan.

\section{UCAPAN TERIMA KASIH}

Artikel ini berasal dari hasil penelitian yang dibiayai DIPA Balai Litbang Agama Jakarta Tahun 2016. Untuk itu, penulis mengucapkan terima kasih kepada Kepala Balai Litbang Agama Jakarta Dra. Hj. Anik Farida, M.Hum. Penulis juga mengucapkan terima kasih kepada Prof. Dr. Imam Tolkhah, MA yang telah memberi komentar terhadap hasil penelitian ini. Selain itu, peneliti juga layak memberikan penghormatan dan rasa terima kasih kepada Kepala Kementerian Agama dan Kepala Dinas Pendidikan Kota Tasikmalaya, Kepala Sekolah SMP Al Muttaqin beserta jajarannya, segenap Pimpinan Pesantren Al Muttaqin beserta pengurus asrama, serta berbagai pihak lain yang membantu proses penelitian hingga tersajinya hasil penelitian ini. Tak lupa penulis haturkan terima kasih kepada redaktur Jurnal Edukasi yang bersedia menerbitkan tulisan ini.

\section{DAFTAR PUSTAKA}

Aulia, T. Y. (2016) Implementasi Kurikulum Pendidikan Agama Islam di SMP Berbasis Pessantren. UIN Sumatera Utara. Available at: http://repository.uinsu.ac.id/1259/1/tesis. pdf.

Azra, A. (1999) Pendidikan Islam: Tradisi dan Modernisasi Menuju Milenium Baru. Jakarta: Logos Wacana Ilmu.

Craib, I. (1992) Teori-Teori Sosial Modern dari Parsons Sampai Habermas. Jakarta: Rajawali Press.

Daradjat, Z. (1992) Ilmu Pendidikan Islam. Jakarta: Diterbitkan atas kerjasama Penerbit Bumi Aksara, Jakarta dengan Direktorat Jenderal Pembinaan Kelembagaan Agama Islam, Departemen Agama.

Draper, P. (2008) 'Handbook of Qualitative Research, 2nd edition edited by Norman 
K. Denzin and Yvonna S. Lincoln. Sage, Thousand Oaks, 2000, 1144 pages, £69.00, ISBN 076191512 5.', Journal of Advanced Nursing, 33(6), pp. 847$847 . \quad$ doi: $10.1111 / \mathrm{j} .1365$ 2648.2001.0472a.x.

Fatah, R. A., Taufik, M. T. and Bisri, A. M. (2005) Rekonstruksi Pesantren Masa Depan: Dari Tradisional, Modern, Hingga Post Modern. Jakarta: Listafariska Putra.

Gunawan, I. (2013) Metode Penelitian Kualitatif. Jakarta: Bumi Aksara.

Hayadin (2017) 'Layanan Pendidikan Agama Sesuai Agama Siswa di Sekolah', EDUKASI: Jurnal Penelitian Pendidikan Agama dan Keagamaan, 1(1). doi: 10.32729/edukasi.v1i1.62.

Iskandar, D. (2010) Sekolah Berbasis Pesantren. Available at: http://mpu.bandaacehkota.go.id/2010/05/ Tim Pelaksana Workshop, Naskah Akademik Workshop "Peningkatan Mutu Pendidikan Agama Islam Melalui Pengembangan Sekolah Berbasis Pesantren", Hotel Syahida Inn, KamisJum'at, 24-35 Mei 2017.

Kementerian Pendidikan dan Kebudayaan. 2010. Panduan Pelaksanaan SMP Berbasis Pesantren. Jakarta: Direktorat Pembinaan Sekolah Menengah Pertama.

Kementerian Pendidikan dan Kebudayaan. 2011. Panduan Penyelenggaraan SMP Berbasis Pesantren. Jakarta: Direktorat Pembinaan Sekolah Menengah Pertama.

Kementerian Pendidikan dan Kebudayaan. 2015. Panduan Penyaluran dan Pemanfaatan SMP Berbasis Pesantren. Jakarta: Direktorat Pembinaan Sekolah Menengah Pertama.

Kementerian Pendidikan dan Kebudayaan. 2016. Laporan Monitoring dan Evaluasi Program Sekolah Berbasis Pesantren Jakarta: Direktorat Pembinaan Sekolah Menengah Pertama.

Tim Peneliti Bidang Pendidikan, Desain Operasional Penelitian "Implementasi
Program Pengembangan Sekolah Berbasis Pesantren” BLA Jakarta, 2016.

19/sekolah-berbasis-pesantren/.

Muhaimin (2012) Pengambangan Kurikulum Pendidikan Agama Islam: Di Sekolah, Madrasah dan Perguruan Tinggi. Jakarta: PT. Raja Grafindo Persada.

Nurochim, N. (2016) 'Sekolah Berbasis Pesantren Sebagai Salah Satu Model Pendidikan Islam Dalam Konsepsi Perubahan Sosial', Al-Tahrir: Jurnal Pemikiran Islam, 16(1), p. 69. doi: 10.21154/al-tahrir.v16i1.320.

Peraturan Pemerintah Nomor 55 Tahun 2007 Tentang Pendidikan Agama dan Keagamaan.

Rosada (2009) 'Integrasi Pendidikan Karakter dalam Pembelajaran IPS di SMP I dan SMP VI Mataram', SOCIA: Jurnal IlmuIlmu Sosial, 6(2), pp. 103-119.

Rusdy, Z. (2016) 'Model Pendidikan Agama Pada Sekolah Berbasis Pesantren'. Jakarta.

Sayuti, W. and Fauzan (2012) Panduan Integrasi Kultur Kepesantrenan ke Dalam Mata Pelajaran. Jakarta: Direktorat Pendidikan Diniyah dan Pondok Pesantren.

Suhardi, D. (2012) 'Peran SMP Berbasis Pesanten Sebagai Upaya Penanaman Pendidikan Karakter Kepada Generasi Bangsa', Jurnal Pendidikan Karakter, (3), pp. 316-328. doi: 10.21831/jpk.v0i3.1248.

Sutrisno and Muhyidin, A. (2012) Pendidikan Islam Berbasis Problem Sosial. Jogjakarta: Ar-Ruz Media.

Suyanto and Suhardi, D. (2014) Pendidikan Berbasis Pesantren. Jakarta: Dirjen Pendidikan Dasar Kemendikbud.

Taqiyah, B. (2016) Pengaruh Pemisahan Kelas Peserta Didik Laki-laki dan Perempuan Terhadap Motivasi Belajar Siswa Kelas X Pada Mata Pelajaran Akidah Akhlak di MA Sunan Pandanaran Yogyakarta. UIN Sunan Kalijaga 
Yogyakarta. Available http://digilib.uin-suka.ac.id/21701/.

Temulus, PP. (2015) Sekolah Berbasis Pesantren. Available at: http://www.pesantrentemulus.or.id/2015/ 11/sekolah-berbasis-pesantren.html. at: Undang-Undang Nomor 20 Tahun 2003 Tentang Sistem Pendidikan Nasional.

Yin, R. K. (2008) Case Study Research: Design and Methods. Fourth Edi. Sage Publications Incorporated. 